\title{
KCNJ5 Gene Mutation
}

National Cancer Institute

\section{Source}

National Cancer Institute. KCN/5 Gene Mutation. NCI Thesaurus. Code C156934.

A change in the nucleotide sequence of the KCNJ5 gene. 